\title{
MYCOFLORA OF SUNFLOWER RHIZOSPHERE IN RELATION TO SOIL FUMIGATION
}

\author{
Aggarwal, A.., Parkash, V., Sharma, D., Sharma, Se., \\ Sharma, Sa., Kaushish, S. and Mehrotra, R.S.
}

Botany Department, Kurukshetra University, Kurukshetra, Haryana, 136119, India

Received: June 12, 2007

Accepted: March 12, 2009

\author{
SUMMARY
}

\begin{abstract}
The present investigation was aimed at analyzing the role of fumigants, i.e., different concentrations of carbon disulphide $\left(\mathrm{CS}_{2}\right)$ and formalin, on soil mycoflora including mycorrhizal fungi in the sunflower rhizosphere. Fungi were greatly reduced immediately after fumigant application but with the passage of time these started to reappear. In qualitative analyses of mycoflora, Aspergillus niger, Aspergillus terreus and Penicillium nigricans reappeared only after 20 days at all $\mathrm{CS}_{2}$ concentrations. The quantitative study showed the boosting up of the population of Trichoderma viride with increasing concentrations of formalin and $\mathrm{CS}_{2}$ after 20 days. High concentrations of both fumigants initially decreased mycorrhizal spore number. However, the mycorrhizal spore number increased later on. Mycorrhizal root colonization reached maximum after 40 days in treated soils. Glomus mosseae was resistant to $\mathrm{CS}_{2}$ application but Glomus geosporum and Acaulospora laevis were inhibited by high concentrations of the fumigant.
\end{abstract}

Key words: sunflower, fumigants, mycoflora, VAM fungi

\section{INTRODUCTION}

Soil contains a large number of diverse microbial populations. Some of these microorganisms are inherently resistant to adverse environmental conditions as soil organic matter protects them from biocidal concentration. There were some situations in agriculture and horticulture where soilborne plant pathogens may be controlled by strong biocidal treatments that affect most sections of the soil microbial population. Carbon disulphide $\left(\mathrm{CS}_{2}\right)$ was the first chemical used as soil fumigant. Fungi including mycorrhizae are more readily killed by fumigants than many bacteria. Many workers have found Trichoderma and Penicillium spp. to be dominant in fumigated soils (Tiwari and Mehrotra, 1973; Kumar, 1995). Saksena (1960) studied the resistance of various soil fungi to fumigants and their ability to recolo-

* Corresponding author 
nize the fumigated soils. In view the above information, two fumigants, i.e., carbon disulphide and formalin, were tested to see their effects on microorganisms including VAM fungi. Another objective was to see the effects of different doses of these fumigants on the population of Trichoderma viride which is used both as a biocontrol agent and a biofertilizer. The effect of two fumigants on plant growth and plant phosphorus content of sunflower was also investigated.

\section{MATERIALS AND METHODS}

\section{Collection of soil samples}

Soil samples were collected from the botanical garden of Botany Department, Kurukshetra University, Kurukshetra, Haryana, India. Soil was sieved for further treatment.

\section{Treatments}

Soil was treated with two fumigants, i.e., formalin and $\mathrm{CS}_{2}$. Two $\mathrm{kg}$ of soil were taken in each pot (size $30 \times 25 \mathrm{~cm}$ ) and fumigants were added to the soil at 2, 4, 6 and $11 \mathrm{ml}$ per $2 \mathrm{~kg}$ of soil. The pots were covered with polythene bags after fumigation so that no fume could escape from them. Polythene covers were removed after $48 \mathrm{~h}$. Healthy seeds of sunflower were sown in each pot. To maintain the moisture needed for seed germination and growth of plants, pots were watered regularly. Soil samples were taken out for mycofloral and mycorrhizal studies after 10, 20, 40 and 70 days. Control pots were kept without any treatment. Five pots of each treatment and control were taken for analyses.

\section{Mycoflora study}

For quantitative and qualitative studies of soil mycoflora, Warcup soil plate method (1950) and Waksman soil dilution method (1927) were used. For mycorrhizal study, the sunflower plants from the treated and control pots were uprooted after regular time intervals of 10,20, 40 and 70 days. Isolation of VAM spores was done by the wet sieving and decanting technique of Gerdemann and Nicolson (1963). Root colonization of VAM fungi was studied by the rapid clearing and staining technique of Philips and Hayman (1970). Growth of sunflower plants was measured after 70 days. For this study, two parameters were measured, i.e., height of plants and phosphorous (P) content of plant shoots and flowers. Phosphorus content of plant shoots and flowers was estimated by the vanadomolybdate phosphoric yellow color method as reported by Jackson (1973). Data were analyzed using the least significant difference test (LSD) and the analysis of variance. 


\section{RESULTS AND DISCUSSION}

Both fumigants had inhibitory effect on soil mycoflora. During the initial 10 days, the inhibitory effect was very pronounced but thereafter the fungitoxic effect decreased and resulted in recurrence of certain fungi. After 10 days, high concentrations of the fumigants $(6 \mathrm{ml} / 2 \mathrm{~kg})$ and $(11 \mathrm{ml} / 2 \mathrm{~kg})$ were completely inhibitory to fungi and no fungal species was recorded. Aspergillus ruber, A. ochraceus, A. luchuensis, A. fumigatus and Penicillium funiculosum were inhibited by carbon disulphide even at a very low concentration $(2 \mathrm{ml} / 2 \mathrm{~kg})$. A. niger and Penicillium nigricans were inhibited by the higher concentrations after 10 days $(6$ and $11 \mathrm{ml} / 2$ $\mathrm{kg}$ ). However, after 10 days, these fungal species reappeared in nearly all treatments. A. terreus and Mucor racemosus were recorded more frequently after 20 days. Trichoderma viride and Curvularia lunata reappeared in the treated soil after 40 days.

Formalin also had deleterious effect on soil mycoflora. Aspergillus terreus and Fusarium oxysporum were resistant to formalin application and these species were present in all the concentrations of the fumigant on all sampling days. Formalin was not completely fungitoxic to all the fungal species at the high concentrations. Inhibitory effect of formalin also decreased with passage of time. Aspergillus ruber, A. ochraceus, A. fumigatus, A. candidus, A. luchuensis and Mucor racemosus were inhibited by formalin. Of the above species, Aspergillus ochraceus and A. fumigatus reappeared after 70 days in the lowest concentration $(2 \mathrm{ml} / 2 \mathrm{~kg})$. Aspergillus flavus and A. niger were found in the $2 \mathrm{ml} / 2 \mathrm{~kg}$ concentration after 40 days. Trichoderma viride was the dominant fungus in the formalin-treated soil in all concentrations.

In the quantitative study, carbon disulphide completely inhibited soil fungi at high concentrations, i.e., $6 \mathrm{ml}$ to $11 \mathrm{ml}$, on the $10^{\text {th }}$ day but larger numbers of fungal species were recorded after 20 days in various concentrations of carbon disulphide. Aspergillus niger, A. terreus and P. nigricans were present in the low concentrations after 10 days and after 20 days were present in all concentrations. Cladosporium cladosporioides, Alternaria alternata, Curvularia lunata and Mucor racemosus were present in the low concentrations of carbon disulphide. Trichoderma viride reappeared after 20 days in the low concentrations and in all concentrations after 70 days.

Aspergillus ochraceus, A. fumigatus, Penicillum chrysogenum and Mucor racemosus were inhibited by formalin in all concentrations. Aspergillus flavus, A. candidus, Fusarium solani, Penicillium funiculosum and Trichoderma viride were present in the high concentrations of formalin after 40 days. Aspergillus terreus and Fusarium oxysporum were relatively resistant to formalin application. Trichoderma viride reappeared after 20 days.

Height of the untreated (control) plants was greater than that of the plants growing in the fumigant-treated soils. The $\mathrm{P}$ content increased in the $\mathrm{CS}_{2}$ treatment with 
$4 \mathrm{ml} / 2 \mathrm{~kg}$, decreased with $6 \mathrm{ml} / 2 \mathrm{~kg}$ and again increased with $11 \mathrm{ml} / 2 \mathrm{~kg}$. Regarding the $\mathrm{P}$ content in flowers, it showed a decreasing trend up to the fumigant concentration of $6 \mathrm{ml} / 2 \mathrm{~kg}$ and then increased after treatment with $11 \mathrm{ml} / 2 \mathrm{~kg}$ (Table 1).

Phosphorus content in plants decreased with increasing formalin concentration but it showed a slight increase at $11 \mathrm{ml} / 2 \mathrm{~kg}$ of formalin. In the case of P content in flowers, it decreased with increasing formalin concentration but showed an increase at the highest concentration, i.e., $11 \mathrm{ml} / 2 \mathrm{~kg}$ soil (Table 1).

Table 1: Effect of carbon disulphide and formalin on the growth and $\mathrm{P}$ content of sunflower

\begin{tabular}{|c|c|c|c|c|c|c|}
\hline \multirow{2}{*}{$\begin{array}{l}\text { Conc. } \\
(\mathrm{ml} / 2 \mathrm{~kg})\end{array}$} & \multicolumn{2}{|c|}{ Height of plants } & \multicolumn{2}{|c|}{ P content in plant (ppm) } & \multicolumn{2}{|c|}{ P content in flower (ppm) } \\
\hline & $\mathrm{CS}_{2}$ & Formalin & $\mathrm{CS}_{2}$ & Formalin & $\mathrm{CS}_{2}$ & Formalin \\
\hline 2 & $83^{\mathrm{a}} \pm 0.47$ & $76^{a} \pm 0.4$ & $2055.6^{a} \pm 0.4$ & $2580.4^{\mathrm{a}} \pm 2.3$ & $6612.6^{a} \pm 0.4$ & $4789.8^{\mathrm{a}} \pm 1.8$ \\
\hline 4 & $96^{\mathrm{b}} \pm 0.94$ & $95^{\mathrm{b}} \pm 2.3$ & $2950.4^{b} \pm 0.4$ & $2394.8^{\mathrm{b}} \pm 0.4$ & $1513.4^{\mathrm{b}} \pm 1.4$ & $4658.8^{\mathrm{b}} \pm 1.4$ \\
\hline 6 & $96^{\mathrm{b}} \pm 1.41$ & $96^{b_{ \pm}} \pm 0.9$ & $1732.2^{c} \pm 0.9$ & $2021.8^{\mathrm{C}} \pm 0.9$ & $1542^{\mathrm{c}} \pm 0.9$ & $4112.4^{\mathrm{c}} \pm 2.8$ \\
\hline 11 & $100^{b c_{ \pm}} \pm 0.27$ & $98^{\mathrm{b}} \pm 1.3$ & $2429^{d} \pm 1.8$ & $2778.4^{\mathrm{d}} \pm 1.4$ & $4583.2^{\mathrm{d}} \pm 1.4$ & $5043.8^{\mathrm{d}} \pm 0.9$ \\
\hline Control & $105^{c_{ \pm}} \pm 1.41$ & $105^{\mathrm{c}} \pm 1.4$ & $1362^{e} \pm 2.35$ & $1362^{\mathrm{e}_{ \pm}} \pm 2.3$ & $6684.4^{\mathrm{e}_{ \pm 1.8}}$ & $6684.4^{\mathrm{e}_{ \pm 1}} \pm$ \\
\hline $\operatorname{LSD}(P=0.05)$ & 8.25 & 5.38 & 6.85 & 6.01 & 12.70 & 2.46 \\
\hline
\end{tabular}

Means in each column that have different letters differ significantly at the 0.05 level of probability

On the $10^{\text {th }}$ day, the mycorrhizal spore number decreased as the concentration of $\mathrm{CS}_{2}$ increased. On the $20^{\text {th }}$ day, the mycorrhizal spore number showed increases at lower concentrations but it showed a decrease at the highest concentration of 11 $\mathrm{ml} / 2 \mathrm{~kg}$ soil. After 40 days onward, the mycorrhizal spore count and root colonization showed a rise with increase in the concentration of the fumigants (Table 2). Table 2 showed that within the treatments, the mycorrhizal spore number increased initially with formalin concentrations increasing up to $6 \mathrm{ml} / 2 \mathrm{~kg}$ soil and then it decreased at the concentration of $11 \mathrm{ml} / 2 \mathrm{~kg}$.

Table 2: Effect of carbon disulphide and formalin on mycorrhizal spore number/100 $\mathrm{g}$ of sunflower at different time intervals

\begin{tabular}{|c|c|c|c|c|c|c|c|c|}
\hline \multirow{2}{*}{$\begin{array}{l}\text { Conc. } \\
\text { (ml/2 kg) }\end{array}$} & \multicolumn{2}{|c|}{$10^{\text {th }}$ day } & \multicolumn{2}{|c|}{$20^{\text {th }}$ day } & \multicolumn{2}{|c|}{$40^{\text {th }}$ day } & \multicolumn{2}{|c|}{$70^{\text {th }}$ day } \\
\hline & $\mathrm{CS}_{2}$ & Formalin & $\mathrm{CS}_{2}$ & Formalin & $\mathrm{CS}_{2}$ & Formalin & $\mathrm{CS}_{2}$ & Formalin \\
\hline Control & $840^{a} \pm 4.7$ & $840^{a} \pm 4.7$ & $936^{\mathrm{a}} \pm 2.8$ & $936^{a} \pm 2.8$ & $648^{a^{2} \pm 3.7}$ & $648^{\mathrm{a}} \pm 3.7$ & $628^{\mathrm{a}} \pm 3.7$ & $628^{\mathrm{a}} \pm 3.7$ \\
\hline 2 & $800^{b} \pm 9.4$ & $890^{\mathrm{b}} \pm 4.7$ & $950^{\mathrm{ab}} \pm 4.7$ & $1028^{\mathrm{b}} \pm 3.7$ & $400^{a} \pm 9.4$ & $600^{\mathrm{b}} \pm 9.4$ & $432^{\mathrm{b}} \pm 0.9$ & $488^{\mathrm{b}} \pm 4.2$ \\
\hline 4 & $775^{c_{ \pm}} \pm 2.3$ & $920^{c} \pm 11.4$ & $965^{\mathrm{b}} \pm 7.4$ & $1112^{\mathrm{C}} \pm 4.7$ & $448^{\mathrm{b}} \pm 3.7$ & $612^{\mathrm{b}} \pm 5.6$ & $556^{c} \pm 2$ & $516^{\mathrm{c}} \pm 7.5$ \\
\hline 6 & $750^{\mathrm{d}} \pm 2.8$ & $920^{c} \pm 14.1$ & $990^{c} \pm 18.8$ & $1270^{\mathrm{d}} \pm 4.7$ & $450^{b} \pm 20.4$ & $368^{\mathrm{C}} \pm 3.7$ & $580^{d} \pm 4$ & $348^{d} \pm 3.7$ \\
\hline 11 & $700^{e} \pm 9.4$ & $600^{d} \pm 20.4$ & $800^{d} \pm 14.1$ & $920^{a} \pm 9.4$ & $504^{\mathrm{C}} \pm 1.8$ & $292^{d} \pm 0.9$ & $628^{\mathrm{e}} \pm 3.7$ & $360^{d} \pm 4.7$ \\
\hline $\operatorname{LSD}(P=0.05)$ & 22.12 & 27.16 & 22.31 & 22.62 & 14.07 & 20.69 & 11.60 & 24.18 \\
\hline
\end{tabular}

Means in each column that have different letters differ significantly at the 0.05 level of probability

Glomus mosseae was resistant to $\mathrm{CS}_{2}$ application. Glomus versiforme, Gigaspora margarita, Gigaspora gigantea were inhibited by $\mathrm{CS}_{2}$ application. Effect of the fumigants was inhibitory during the initial 20 days after treatment and then this deleterious effect decreased. Glomus reticulatum, Glomus aggregatum, Glomus fasciculatum, Acaulospora foveata and Acaulospora sp. were recorded 
after 20 days at the high concentrations. In the case of formalin treatment, the VAM species decreased in comparison with the untreated control. Fungal species recorded after the $20^{\text {th }}$ day were more numerous than before that. Glomus geosporum, Glomus gilmorei and Glomus diaphanum were inhibited by formalin. Glomus intraradices, Glomus reticulatum and Glomus fasciculatum were resistant to formalin application. Glomus mosseae, Glomus versiforme, Acaulospora laevis and Glomus sp. I were recorded more frequently, even at high concentrations, after 20 days but Acaulospora foveata, Glomus sp. II and Glomus caledonicum were recorded seldom.

Mycorrhizal root colonization decreased with increase in $\mathrm{CS}_{2}$ concentration of up to the $40^{\text {th }}$ day but after the $70^{\text {th }}$ day it leveled off. The number of vesicles present in the various concentrations of $\mathrm{CS}_{2}$ was low, with minimum numbers being present at the highest concentration of $\mathrm{CS}_{2}$ (Table 3).

Table 3: Effect of carbon disulphide and formalin on percentage mycorrhizal root colonization of sunflower at different time intervals

\begin{tabular}{lcccccccc}
\hline \multirow{2}{*}{$\begin{array}{l}\text { Conc. } \\
(\mathrm{ml} / 2 \mathrm{~kg})\end{array}$} & \multicolumn{2}{c}{$10^{\text {th }}$ day } & \multicolumn{2}{c}{$20^{\text {th }}$ day } & \multicolumn{2}{c}{$40^{\text {th }}$ day } & \multicolumn{2}{c}{$70^{\text {th }}$ day } \\
\cline { 2 - 9 } & $\mathrm{CS}_{2}$ & Formalin & $\mathrm{CS}_{2}$ & Formalin & $\mathrm{CS}_{2}$ & Formalin & $\mathrm{CS}_{2}$ & Formalin \\
\hline Control & $84.61^{\mathrm{a}} \pm 0.47$ & $84.16^{\mathrm{a}} \pm 0.47$ & $86.36^{\mathrm{a}} \pm 0.4$ & $86.36^{\mathrm{a}} \pm 0.4$ & $100^{\mathrm{a}} \pm 0$ & $100^{\mathrm{a}} \pm 0$ & $100^{\mathrm{a}} \pm 0$ & $100^{\mathrm{a}} \pm 0$ \\
2 & $83.33^{\mathrm{a}} \pm 0.95$ & $100^{\mathrm{b}} \pm 0$ & $85^{\mathrm{a}} \pm 2.3$ & $100^{\mathrm{b}} \pm 0$ & $100^{\mathrm{a}} \pm 0$ & $100^{\mathrm{a}} \pm 0$ & $100^{\mathrm{a}} \pm 0$ & $100^{\mathrm{a}} \pm 0$ \\
4 & $37.50^{\mathrm{b}} \pm 1.65$ & $91.66^{\mathrm{c}} \pm 0.4$ & $50^{\mathrm{b}} \pm 0.9$ & $94^{\mathrm{c}} \pm 0.4$ & $75^{\mathrm{b}} \pm 2.3$ & $100^{\mathrm{a}} \pm 0$ & $100^{\mathrm{a}} \pm 0$ & $100^{\mathrm{a}} \pm 0$ \\
6 & $37.50^{\mathrm{b}} \pm 0.47$ & $91.66^{\mathrm{c}} \pm 0.9$ & $50^{\mathrm{b}} \pm 2.3$ & $94^{\mathrm{c}} \pm 0.5$ & $75^{\mathrm{b}} \pm 0.4$ & $100^{\mathrm{a}} \pm 0$ & $100^{\mathrm{a}} \pm 0$ & $100^{\mathrm{a}} \pm 0$ \\
11 & $36.30^{\mathrm{b}} \pm 0.94$ & $73.68^{\mathrm{d}} \pm 1.8$ & $45^{\mathrm{b}} \pm 0.9$ & $78^{\mathrm{d}} \pm 0.4$ & $69^{\mathrm{b}} \pm 0.9$ & $88^{\mathrm{b}} \pm 0.9$ & $100^{\mathrm{a}} \pm 0$ & $100^{\mathrm{a}} \pm 0$ \\
LSD $(\mathrm{P}=0.05)$ & 1.93 & 1.93 & 5.38 & 5.38 & 11.1 & 9.8 & 2.71 & 5.90 \\
\hline
\end{tabular}

Means in each column that have different letters differ significantly at the 0.05 level of probability.

In the case of formalin (Table 3 ), the percentage of mycorrhizal root colonization increased initially at $2 \mathrm{ml}$ concentration and then it showed a decreasing trend. After 40 days, the mycorrhizal root colonization reached $100 \%$ in all formalin concentrations but the highest one $(11 \mathrm{ml})$.

In the present investigation, the fumigants, i.e., carbon disulphide and formalin, had an inhibitory effect on soil microorganisms up to the $10^{\text {th }}$ day after treatment. After 10 days both the fumigants were less inhibitory in comparison to control but Trichoderma viride population increased with formalin treated soil after 10 days. As mentioned earlier the Trichoderma population increased after 10 days with formalin treatment, Wainwright (1977) suggested that dominance of this fungus might be due to their ability to utilize $\mathrm{NH}_{4}{ }^{+}-\mathrm{N}$, which is amply available in fumigated soil, or to resistance of mycostasis caused by $\mathrm{NH}_{3}$. Martin et al. (1963) reported that there is marked reduction of fungal population after fumigation with carbon disulphide, chloropicrin and ethylene dibromide.

In the case of formalin treatment, lower concentrations were stimulatory but higher concentrations were inhibitory to VAM fungi. According to Bird et al. (1974), O'Bannon and Nemec (1978), most of the fumigants except ethylene dibromide were toxic to VAM fungi. Hayman (1970) indicated that formalin applied in previous year decreased the number of Endogone sp. in subsequent year. Fumigation of soil with 
broad-spectrum biocides such as methyl bromide, formalin and $\mathrm{CS}_{2}$ can greatly reduce vesicular-arbuscular mycorrhizal formation (An et al., 1993; Trappe et al., 1984). Hayman (1970) reported of mycorrhizal fungi surviving high concentrations of fumigation, which indicated that that the tested fungal populations were resistant to fumigation.

In the present investigation, $\mathrm{CS}_{2}$ showed different effect on VAM species at different concentrations. Glomus mosseae appeared to be resistant to all concentrations up to the $70^{\text {th }}$ day. Similarly, the effect of formalin on VAM species showed that Glomus intraradices, Glomus reticulatum and Glomus fasciculatum were resistant to most of the concentrations of both fumigants. Spokes and McDonald (1978) showed that fumigants did not affect mycorrhizal root colonization by Glomus fasciculatum but these fumigants reduced the colonization by Glomus mosseae to $2 / 3$ of the control. Soil fumigation may kill beneficial microorganisms such as bacteria and actinomycetes that can improve spore number and root colonization of VAM fungi.

Regarding the effect of both fumigants on sunflower growth and $\mathrm{P}$ content, it was clear that the height of plants decreased in comparison with the control. However, the $\mathrm{P}$ content in plants increased but the content in flowers decreased in comparison with the control. There had been consistent reports of plant stunting following fumigation (Lambert et al., 1979; Vyas and Singh, 1992). After prolonged research, the problem of stunting following fumigation was explained by Filler and Tayler (1968), who demonstrated that mycorrhizal inoculation increased the growth of tree seedlings in the soil fumigated with methyl bromide. Afek et al. (1990) reported that fresh weight and yield were one to two times greater in nonfumigated than in fumigated soil in the cases of cotton, onion and pepper. Fumigants with relatively high vapor pressure potential are able to move over greater distances in the soils than the compounds with low volatility (Laiho and Mialo, 1965). Finally, soil fumigants may not persist for a long period but delay in reintroduction of mycorrhizal fungi may produce disastrous stunting of host plants over several years. It may be concluded from this investigation that microorganisms including mycorrhizae are vital components of most agronomic systems. The effects of fumigants on non-target microorganisms including mycorrhizal fungi must be assessed carefully and fumigants should be intelligently used in agricultural systems.

\section{CONCLUSIONS}

High concentration of the two investigated fumigants initially decreased the mycorrhizal spore number but later on the number was increased in all concentrations of the fumigants. Mycorrhizal root colonization reached $100 \%$ on the $70^{\text {th }}$ day both in the control and in the fumigated soil. It was found that the fumigants inhibited the growth of all test fungi. Growth of sunflower plants increased concurrently with the increase in the concentration of fumigants. Phosphorous content of the treated plants showed a decrease followed by an increase at the higher fumigant concentrations. Thus, the high dosages of both fumigants caused adverse effects on soil microflora, mycorrhizal fungi and plant growth. Therefore, the use of both 
fumigants at high dosages as well as their continuous application should be conducted in a judicious manner.

\title{
ACKNOWLEDGEMENTS
}

\author{
The authors Vipin Parkash and Dipti Sharma gratefully acknowledge \\ financial assistance from CSIR, New Delhi.
}

\section{REFERENCES}

Afek, U., Menge, J.A. and Johnson, E.L.V., 1990. Effect of Pythium ultimum and metalaxyl treatments on root length and mycorrhizal colonization of cotton, onion and pepper. Plant Dis. 74: 117-120.

An, Z.Q., Hendrix, J.W., Hershman, D.E., Ferriss, R.S. and Henson, G.T., 1993. The influence of crop rotation and soil fumigation on a mycorrhizal fungal community associated with soybean. Mycorrhiza 3: 171-182.

Bird, G.W., Rich, J.R. and Glover, S.W., 1974. Increased endomycorrhizae of cotton roots in soil treated with nematicides. Phytopathology 64: 48-51.

Filler, T.H. and Tayler, E.R., 1968. Effect of methyl bromide on mycorrhizae and growth of sweetgum seedlings. Plant Dis. Reptr. 52: 483.

Gerdemann, J.W. and Nicolson, Y.H., 1963. Spores of mycorrhizae Endogone species extracted from soil by wet sieving and decanting. Trans. Brit. Mycol. Soc. 46: 235-244.

Hayman, D.S., 1970. Endogone spore numbers in soil and vesicular-arbuscular mycorrhiza in wheat as influenced by season and soil treatment. Trans. Brit. Mycol. Soc. 54(1): 53-63.

Jackson, M.L., 1973. Chemical analysis. Prentice Hall of India Ltd. New Delhi, India.

Kumar, J., 1995. Studies on Indian species of Trichoderma and Gliocladium with special reference to the production of metabolites and biocontrol of some important soil borne and aerial pathogens. Ph.D. Thesis, Kurukshetra University, Kurukshetra India, pp. 158.

Laiho, O. and Mialo, P., 1965. Studies on the effect of some eradicants on mycorrhizal development in forest nurseries. Act. For. Fenn. 77: 33.

Lambert, D.H., Stouffer, R.F. and Cole, H.Jr., 1979. Stunting of peach seedlings following soil fumigation. J. Am. Soc. Hort. Sci. 104: 433.

Martin, J.P., Baines, R.C. and Page, A.L., 1963. Observations on the occasional temporary growth inhibition of citrus seedlings following heat or fumigation treatment of the soil. Soil and Sci. 95: 175-185.

O'Bannon, J.H. and Nemec, S., 1978. Influence of soil pesticides on vesicular-arbuscular mycorrhizae in a citrus soil. Nematropica 8: 56-61.

Phillips, J.M. and Hayman, D.S., 1970. Improved produces for clearing roots and staining parasitic and VAM fungi for rapid assessment of infection. Trans. Brit. Mycol. Soc. 55: $158-161$.

Saksena, S.B. 1960. Effect of carbon disulphide fumigation on Trichoderma viride and other soil fungi. Trans. Brit. Mycol. Soc. 43: 111-116.

Spokes, J.R. and MacDonald, R.M. 1978. Effects of pesticides on VA mycorrhizae. Rep. Rothmansted Exp. Stn. for 1978, Part 1, pp. 236-350.

Tiwari, D.P. and Mehrotra, R.S., 1973. Survival and control of Phytophthora parasitica in fumigated soils. J. Indian Bot. Soc. 52: 138.

Trappe, J.M., Molina, R. and Castellano, M., 1984. Reactions of mycorrhizal fungi and mycorrhiza in formation to pesticides. Ann. Rev. Phytopath. 22: 331-359.

Vyas, S.C. and Singh, S., 1992. Role of fungicides in the formation of vesicular arbuscular mycorrhiza in plants. Mycorrhiza News 4(3): 1-6.

Wainwright, M., 1977. Effect of fungicides on the microbiology and biochemistry of soils - A review. Z. Pflazenernaehr. Bodenkol. 140: 587.

Waksman, S.A., 1927. Principle of soil microbiology. Williams and Willkins Co., Baltimore, Maryland, pp. 897.

Warcup, J.H., 1950. The soil plate method for the isolation of fungi from soil. Nature 166: 117118. 


\title{
MICROFLORA DE LA RIZÓSFERA DE GIRASOL EN RELACIÓN A LA FUMIGACIÓN DEL SUELO
}

\author{
RESUMEN
}

El objetivo de la presente investigación fue analizar el rol de los fumigantes disulfuro de carbono $\left(\mathrm{CS}_{2}\right)$ y formalin a diferentes concentraciones sobre la microflora del suelo incluyendo las micorrizas de la rizósfera del girasol. La población de hongos se redujo fuertemente inmediatamente después de la aplicación del fumigante pero con el paso del tiempo ésta comenzó a reaparecer. En análisis cuantitativos de microflora Aspergillus niger, Aspergillus terreus y Penicillium nigricans hicieron su aparición sólo después de veinte días de la aplicación de $\mathrm{CS}_{2}$ a todas las concentraciones. Estudios cuantitativos mostraron el incremento de la población de Trichoderma viride con el aumento de la concentración de Formalin y $\mathrm{CS}_{2}$ después de los veinte días. Inicialmente ambos fumigantes disminuyeron el número de esporas de micorrizas a las concentraciones más altas. Sin embargo, el número de esporas de micorrizas se incrementó más adelante. La colonización de raíces con micorrizas fue máxima después de cuarenta días en suelos tratados. Glomus mosseae fue resistente a la aplicación de $\mathrm{CS}_{2}$ pero Glomus geosporum y Acaulospora laevis se inhibieron a altas concentraciones.

\section{LA MYCOFLORE DE LA RHIZOSPHÈRE DU TOURNESOL EN RAPPORT AVEC LA FUMIGATION DU SOL}

\author{
RÉSUMÉ
}

Cette recherche avait pour but d'analyser le rôle des fumigants - disulfure de carbone $\left(\mathrm{CS}_{2}\right)$ et formaline - à différentes concentrations sur la mycoflore du sol, y compris les champignons mycorrhiziens, de la rhizosphère du tournesol. La présence des champignons a été considérablement réduite immédiatement après l'application du fumigant mais avec le temps, ils ont commencé à réapparaître. Dans les analyses qualitatives de la mycoflore, Aspergillus niger, Aspergillus terreus, Penicillium nigricans sont réapparus seulement 20 jours après l'application du CS2, quelque soit la concentration. L'étude quantitative a montré une augmentation de la population de Trichoderma viride avec l'augmentation des concentrations de Formaline et de CS2, 20 jours après le traitement. Les deux fumigants ont fait décroître initialement le nombre de spores mycorrhiziennes aux concentrations les plus fortes. Toutefois, le nombre de spores mycorrhiziennes a été en augmentation plus tard. La colonisation mycorrhizienne des racines est devenue maximale dans les sols traités 40 jours après le traitement. Glomus mosseae s'est montré resistant à l'application de $\mathrm{CS}_{2}$ application mais Glomus geosporum, Acaulospora laevis ont été inhibés aux concentrations les plus fortes. 